\title{
Evaluation of olfactory function in migraineurs during the migraine-free period with odor identification test
}

\author{
Migren hastalarında atak olmayan dönemde koku tanımlama testi ile \\ koku fonksiyonunun değerlendirilmesi
}

\author{
Hakan Tekeli', Mehmet Güney Şenol', Fatih Özdağ', Mehmet Saraçoğlu², Halit Yaşar³, Mustafa Tansel Kendirli', \\ Aytuğ Altundağ ${ }^{4}$, Melih Çayönü, Murat Salihoğlư ${ }^{6}$, Türker Türker \\ ${ }^{1}$ Department of Neurology, GATA Haydarpasa Training Hospital, Istanbul, Turkey \\ ${ }^{2}$ Division of Neurology, Istanbul Surgery Hospital, Istanbul, Turkey \\ ${ }^{3}$ Division of Neurology, GATA Mevki Hospital, Ankara, Turkey \\ ${ }^{4}$ Division of Otorbinolaryngology, Istanbul Surgery Hospital, Istanbul, Turkey \\ 5 Department of Otorbinolaryngology, Amasya University Training and Research Hospital, Amasya, Turkey \\ ${ }^{6}$ Department of Otorbinolaryngology, GATA Haydarpaşa Training Hospital, Istanbul, Turkey \\ ${ }^{7}$ Department of Public Health, GATA Ankara Training Hospital, Ankara, Turkey
}

\begin{abstract}
Objective: Despite the fact that there are many studies about the osmophobia and migraine, we have very little knowledge about the olfactory abilities of migraineurs during the period between the attacks. So, the aim of this study was to evaluate the olfactory function of migraineurs during the period without headaches with odor identification test.

Methods: Two hundred and ninety healthy people aged 16 to 65 years (152 female, 138 male) and 84 migraine patients aged 18 to 55 years ( 47 female, 37 male) were studied. The participants with migraine were selected from the patients who applied to headache outpatient clinic for assessment. Participants, appropriate to the study, were physically and neurologically examined in detail and then they were taken to the test room in order to be screened with Short Smell Test Battery of GATA Haydarpaşa (GULTEST).

Results: The mean GULTEST score of the migraine group was less than the healthy group and the difference was significant. The effect of gender, cigarette smoking and disease status (migraine) on GULTEST scores was evaluated by linear regression model. It was found that females had higher odor identification scores than males in both migraineurs and controls. On the other hand, cigarette smoking had a significant negative effect on GULTEST scores. Furthermore, migraine had a significant negative effect on GULTEST scores.

Conclusion: Our study showed that even during the headache-free period, migraineurs might have reduced olfactory abilities.
\end{abstract}

Keywords: Migraine, smell, olfaction disorders, headache.

\section{Özet}

Amaç: Osmophobia ve migren konusunda birçok çalışmanın varlığına rağmen, migren hastalarının ataklar arası dönemde koku alma yetenekleri hakkında çok az bilgiye sahibiz. Bu nedenle bu çalışmanın amacı migren hastalarının başağrısı olmayan dönemde koku tanımlama testi ile koku alma fonksiyonlarının değerlendirilmesidir.

Yöntem: Yaşları 16-65 arasında olan 290 sağlıklı birey (152 kadın, 138 erkek) ve yaşları 18-55 arasında olan 84 migren hastası (47 kadın, 37 erkek) çalışmaya dahil edildi. Migreni olan katılımcılar değerlendirilmek üzere başağrısı polikliniğine başvuran hastalardan seçildi. Çalışmaya uygun olan katılımcılar nörolojik ve fiziksel olarak detaylı bir şekilde değerlendirildi ve daha sonra GATA Haydarpaşa Kısa Koku Test Bataryası (GULTEST) ile değerlendirme yapılması için test odasına alındı. Bulgular: Migren grubunun ortalama GULTEST skoru sağlıklı gruba göre daha az idi ve fark anlamlıydı. GULTEST skorlarına cinsiyetin, sigara içmenin ve hastalık durumunun (migren) etkisi lineer regresyon modeli ile değerlendirildi. Hem migren hastalarında hem de sağlıklı kontrollerde kadınların erkeklere göre daha yüksek koku tanımla skorları aldıkları saptandı. Buna karşılık, sigara içmenin GULTEST skorları üzerinde anlamlı bir olumsuz etkisi vardı. Ayrıca, migrenin de GULTEST skorları üzerinde anlamlı bir olumsuz etkisi vardi.

Sonuç: Araştırmamız migren hastalarında başağrısı olmadığı dönemlerde dahi koku alma yeteneklerinin azalmış olabileceğini göstermiştir.

Anahtar sözcükler: Migren, koku, koku alma bozuklukları, başağrısı.
Correspondence: Melih Çayönü, MD. Department of Otorhinolaryngology, Amasya University Training and Research Hospital, Kirazlidere, 05100, Turkey. e-mail: melihcayonu@yahoo.com

Received: January 7, 2014; Accepted: February 13, 2014; Published online: May 5, 2014
Online available at: www.jmedupdates.org doi: $10.2399 /$ jmu. 2014001001 QR code: 
The existence of migraine has been known for thousands of years and millions of people suffer from migraine symptoms. Migraine is considered to be an episodic primary headache with several combinations of neurologic, gastrointestinal and autonomic features. ${ }^{[1,2]}$ The lifelong prevalence of migraine in a general population has been estimated to be $16 \%$, whereas there was a significant predominance in females; lifelong prevalence is $~ 25 \%$ in females, and $~ 8 \%$ in males. ${ }^{[1,2]}$

Migraine patients have strong sensitivity to smells, resulting in olfactory aura which is an indicator of an approaching migraine episode. As it is named osmophobia, it refers to an increased sensitivity to certain odors during migraine attacks, which could cause avoidance of those odors or aggravation of migrainous symptoms. It occurs in $24.7-47.7 \%$ of adult migraine patients according to previous epidemiological studies, and has been reported to be quite specific for the diagnosis of migraine, especially in the absence of nausea or vomiting. ${ }^{[3-6]}$

The olfactory function generally fails in one of three ways. One is an intensity reduction resulting in decreased olfactory sensitivity (hyposmia or anosmia), also called quantitative olfactory disorders. ${ }^{[7,8]}$ The other two are quality changes with a distortion of the perceived odor, also called qualitative olfactory dysfunction. One type of distortion occurs when inhaled odorants do not have the same smell or odor as remembered (parosmia). The other type of distortion is the perception of an odor (usually unpleasant) when there is no odorant in the environment (phantosmia, hallucination). ${ }^{[7,8]}$

There are studies that have described olfactory dysfunction among migraineurs. Olfactory stimuli can precipitate migraine, and olfactory hallucinations can occur as auras of migraines or as part of the symptom complex. ${ }^{[9-14]}$ Despite many reports linking distorted olfactory perception and migraine, we have very little knowledge about the quantitative olfactory abilities of migraineurs. ${ }^{[15,16]}$ Thus, the aim of this study was to evaluate the olfactory functions of migraineurs during the migraine-free period.

\section{Materials and Methods}

A total of 290 healthy people and 84 migraine patients were included in this case-controlled clinical study. The healthy control group consisted of 152 females and 138 males aged 16 to 65 years whereas the migraine patients group consisted of 47 females and 37 males aged 18 to 55 years. Informed consent was obtained from all participat- ing subjects. This study was approved by the Institutional Review Board of Gülhane Military Medicine Academy (GATA) Haydarpaşa Training Hospital.

The patients with migraine were selected from the patients who were following up by the Headache Outpatient Clinic of Neurology Department of GATA Haydarpaşa Training Hospital and they were invited to the study by phone calls. Control subjects suffered neither migraines nor other chronic headaches and had no family history of migraine headache. Headaches were diagnosed based on the international classification of headache disorders (ICHD)-II..$^{[17]}$

All the subjects were asked to fill a questionnaire form including questions about age, education, smoking cigarette, any known olfactory dysfunction, any operation of nose, recent upper respiratory illness and severe head trauma history. Individuals who answered "yes" to the any of last four questions were not included in the study. Also all the individuals were evaluated with nasal endoscopy by the ear nose throat doctors and individuals with signs of nasal polyposis or rhinosinusitis were not included in the study.

\section{Psychophysical Testing of Olfactory Function}

Patients, found to be appropriate for the study, were physically and neurologically examined in detail and then they were taken to the test room in order to be screened with Short Smell Test Battery of GATA Haydarpaşa (GULTEST). The olfactory test was performed during migraine-free periods. GULTEST was prepared like this: Three layers of first quality blotter paper were cut to fit on the base of Fonart brand air proof pallet containers. Pure odor essences were put in the containers without being diluted by water. Every container's bottom was marked with a number of odor so that the patients could not see it.

The odor samples used in the GULTEST are presented in Table 1, and these odor samples were well-known by every segment of our society. During the test, every patient was asked to smell an odor for 5 seconds and name

Table 1. Odor samples used for olfactory testing (GULTEST).

\begin{tabular}{ccc}
\hline No & Odor & Description-Accepted \\
\hline 1 & Banana & Lovely fruit \\
2 & Mint & Menthol \\
3 & Rose & Lovely flower \\
4 & Lemon & Orange \\
5 & Chocolate & Cacao \\
\hline
\end{tabular}


it. The odors were selected randomly from the tray. The answers were marked on the answer sheet. During the evaluation of the test, similar naming for the odors; such as instead of "rose" telling "nice flower" or instead of "chocolate" telling "cocoa" were accepted as true answers. For every correct answer, 1 point was recorded to the score section. The test was applied in a ventilated and air filtered area in order to prevent any additional odors that could affect the test. The patients were not tested consecutively in the same area.

The measurements in the healthy participants allowed us to determine the normal values for GULTEST.

\section{Statistical Analysis}

Data analysis was performed by SPSS 21.0 (Statistical Package for Social Sciences; SPSS Inc., Chicago, IL, USA). The normal distribution of considered variables was first evaluated using the Shapiro-Wilk test. Data were shown as mean \pm standard deviation for continuous variables and number of cases was used for categorical ones. Demographic data of the subjects were compared by t test or chi-square test. Also the effect of disease status on GULTEST scores was examined with a linear regression model. Correlational analyses were calculated according to Pearson. The level of significance was set at 0.05 .

\section{Results}

The study was carried out in 374 subjects, and the mean age of the participants was $35.3 \pm 1$ years, ranging from 16 to 65 . Two age and sex matched study groups were established. The first group consisted of healthy people to standardize the GULTEST. And the second group consisted of 84 migraine patients. Also, there were no differences between the groups in terms of education level and cigarette smoking. Table 2 gives the summary of characteristics of each of the variables of interest by groups.

The mean GULTEST score of the migraine group was less than the healthy group and the difference was significant. The effect of gender, cigarette smoking and disease status (migraine) on GULTEST scores was evaluated by linear regression model. It was found that females had higher identification scores than males in both migraineurs and controls ( $\mathrm{p}=0.02)$. On the other hand, cigarette smoking had a significant negative effect on GULTEST scores $(\mathrm{p}=0.03)$. Furthermore, migraine had a significant negative effect on GULTEST scores $(\mathrm{p}<0.001)$.

\section{Discussion}

The studies to evaluate olfactory function have started from bedside clinical applications and with the developing technology they progressed to a very wide scale, including intracellular recordings, electro-olfactogram examinations, use of odor in qualitative and quantitative EEG, evoked responses and Olfactory Event Related Potential (OERP) recordings. There are numerous ways of assessing the nasal chemosensory performance (e.g., the University of Pennsylvania Smell Identification Test, UPSIT, ${ }^{[18]}$ "Sniffin' Sticks" ${ }^{[19,20]}$ or measurements of event-related potentials ${ }^{[21]}$ ) which has been validated for various countries and populations. However none of these olfactory testing kits were validated in our country.

That's why in our study, odors which are assumed to be known very well in the Turkish population are used. No differentiation of the odor and unrelated naming have been considered as pathological. In order to detect the GULTEST scores easier a total of 5 odor samples were presented. According to GULTEST scores, the major finding of this current investigation was the significant negative effect of migraine on olfactory function.

There were little data and conflicting publications in the literature about the olfactory abilities of migraine patients. Snyder and Drummond ${ }^{[15]}$ have reported that patients with migraine showed a lower threshold than the control group for sensing a vanillin odor, and Hirsch ${ }^{[16]}$ reported that patients with migraine exhibited a higher threshold for sensing a pyridine odor. Our data support the idea that identification scores were diminished due to migraine.

The olfactory disorders generally known to be associated with migraine are qualitative olfactory dysfunctions;

Table 2. Demographic data and other characteristics of the study groups.

\begin{tabular}{lccc}
\hline Characteristics & $\begin{array}{c}\text { Healthy group } \\
(\mathbf{n}=\mathbf{2 9 0 )}\end{array}$ & $\begin{array}{c}\text { Migraine group } \\
(\mathbf{n}=\mathbf{8 4})\end{array}$ & $\mathbf{p}$ \\
\hline Age & $35.5 \pm 11.3$ & $34.6 \pm 8.7$ & 0.5 \\
Male participants (\%) & $138(47.5 \%)$ & $37(44 \%)$ & 0.7 \\
Education level & & & \\
$\quad$ Primary school (\%) & $40(13.8 \%)$ & $6(7.1 \%)$ & 0.14 \\
Secondary school (\%) & $26(9 \%)$ & $9(10.7 \%)$ & \\
High school (\%) & $103(35.5 \%)$ & $24(28.6 \%)$ & \\
University (\%) & $121(41.7 \%)$ & $45(53.6 \%)$ & \\
Smoking (\%) & $135(46 \%)$ & $33(39 \%)$ & 0.2 \\
GULTEST score & $3.4 \pm 0.9$ & $2.8 \pm 0.8$ & $<0.001$ \\
GULTEST score (males) & $3.31 \pm 0.8$ & $2.6 \pm 0.9$ & $<0.001$ \\
GULTEST score (females) & $3.46 \pm 0.89$ & $2.91 \pm 0.72$ & $<0.001$ \\
\hline
\end{tabular}


parosmia $^{[8]}$ or osmophobia. ${ }^{[14]}$ Qualitative olfactory dysfunctions can be classified into central or peripheral depending on their respective origins. Central causes can be related to an area of hyper-functioning brain cells generating this odor perception. ${ }^{[22]}$ This typically lasts only a few seconds. Some individuals with phantosmias have commented that they can feel a phantom odor coming before it actually arrives. This olfactory distortion can exist with epilepsy, migraine, and psychiatric etiologies like schizophrenia, depression, alcoholic psychosis, and olfactory reference syndrome. ${ }^{[23]}$

Evaluation of the olfactory function in terms of both qualitative and quantitative is becoming more important for diagnosis of neurologic disorders. Decrease in recognition of odor is one of the primary symptoms of olfactory dysfunction such as in Alzheimer's disease and this dysfunction has been shown by a variety of odor recognition tests. ${ }^{[24-26]}$ Although there are well developed odors test scales for neurodegenerative disorders, such as dementia, there are only a few studies in the literature which have studied olfactory dysfunction in headache patients. Significant differences between odor identification scores of healthy group and migraine group were observed in our study. However, our study has some limitations. It should be better to group the migraine patients according to the presence of aura. Also the distorted olfactory perception should be studied together with quantitative olfactory disorders.

\section{Conclusion}

There are still many things to learn about olfactory dysfunction and migraine. Further knowledge of olfactory pathophysiology and migraine concerning the underlying mechanisms behind the most common forms of olfactory disorders is lacking. For all that, the current investigation showed that the migraine might be significant negative effect on olfactory function.

Conflict of Interest: No conflicts declared.

\section{References}

1. Stovner LJ, Zwart JA, Hagen K, Terwindt GM, Pascual J. Epidemiology of headache in Europe. Eur J Neurol 2006;13:333-45.

2. Russell MB, Rasmussen BK, Thorvaldsen P, Olesen J. Prevalence and sex-ratio of the subtypes of migraine. Int J Epidemiol 1995;24: 612-8.

3. Kelman L. The place of osmophobia and taste abnormalities in migraine classification: a tertiary care study of 1237 patients. Cephalalgia 2004;24:940-6.
4. Kelman L. Osmophobia and taste abnormality in migraineurs: a tertiary care study. Headache 2004;44:1019-23.

5. Morillo LE, Alarcon F, Aranaga N, et al. Clinical characteristics and patterns of medication use of migraineurs in Latin America from 12 cities in 6 countries. Headache 2005;45:118-26.

6. Zanchin G, Dainese F, Trucco M, et al. Osmophobia in migraine and tension-type headache and its clinical features in patients with migraine. Cephalalgia 2007;27:1061-8.

7. Frasnelli J, Hummel T. Olfactory dysfunction and daily life. Eur Arch Otorhinolaryngol 2005;262:231-5.

8. Hong SC, Holbrook EH, Leopold DA, Hummel T. Distorted olfactory perception: a systematic review. Acta Otolaryngol 2012; 132 Suppl 1:S27-31.

9. Demarquay G, Royet JP, Giraud P, Chazot G, Valade D, Ryvlin P. Rating of olfactory judgements in migraine patients. Cephalalgia 2006:26:1123-30

10. Zanchin G, Dainese F, Mainardi F, Mampreso E, Perin C, Maggioni F. Osmophobia in primary headaches. J Headache Pain 2005;6:213-5.

11. Sjöstrand C, Savic I, Laudon-Meyer E, Hillert L, Lodin K, Waldenlind E. Migraine and olfactory stimuli. Curr Pain Headache Rep 2010;14:244-51.

12. Stankewitz A, May A. Increased limbic and brainstem activity during migraine attacks following olfactory stimulation. Neurology 2011;77:476-82.

13. Coleman ER, Grosberg BM, Robbins MS. Olfactory hallucinations in primary headache disorders: case series and literature review. Cephalalgia 2011;31:1477-89.

14. Saisu A, Tatsumoto M, Hoshiyama E, Aiba S, Hirata K. Evaluation of olfaction in patients with migraine using an odour stick identification test. Cephalalgia 2011;31:1023-8.

15. Snyder RD, Drummond PD. Olfaction in migraine. Cephalalgia 1997;17:729-32.

16. Hirsch AR. Olfaction in migraineurs. Headache 1992;32:233-36.

17. Headache Classification Subcommittee of the International Headache Society. The international classification of headache disorders: 2nd edition. Cephalalgia 2004;24 Suppl 1:9-160

18. Doty RL, Shaman P, Dann M. Development of the University of Pennsylvania Smell Identification Test: a standardized microencapsulated test of olfactory function (UPSIT). Physiol Behav 1984;32:489-502.

19. Hummel T, Sekinger B, Wolf S, Pauli E, Kobal G. "Sniffin' Sticks": olfactory performance assessed by the combined testing of odor identification, odor discrimination and olfactory threshold. Chem Senses 1997;22:39-52.

20. Kobal G, Klimek L, Wolfensberger M, et al. Multicenter investigation of 1,036 subjects using a standardized method for the assessment of olfactory function combining tests of odor identification, odor discrimination, and olfactory thresholds. Eur Arch Otorhinolaryngol 2000;257:205-11.

21. Kobal G, Hummel T. Olfactory and intranasal trigeminal eventrelated potentials in anosmic patients. Laryngoscope 1998;108: $1033-5$. 
22. Leopold DA, Myerrose G. Diagnosis and treatment of distorted olfactory perception. In: Kurihara K, Suzuki N, Ogawa H, editors. Olfaction and taste XI. Tokyo: Springer-Verlag; 1994. p. 618-22.

23. Leopold DA. Distorted olfactory perception. In: Doty RL, editor. Handbook of olfaction and gustation. New York: Marcel Dekker; 1995. p. 441-54.

24. Conti MZ, Vicini-Chilovi B, Riva M, et al. Odor identification deficit predicts clinical conversion from mild cognitive impairment to dementia due to Alzheimer's disease. Arch Clin Neuropsychol 2013;28:391-9.

25. Schofield PW, Ebrahimi H, Jones AL, Bateman GA, Murray SR. An olfactory 'stress test' may detect preclinical Alzheimer's disease. BMC Neurol 2012;12:24.

26. Murphy C, Bacon AW, Bondi MW, Salmon DP. Apolipoprotein E status is associated with odor identification deficits in "normal" older persons. Ann NY Acad Sci 1998;855:744-50.

This is an open access article distributed under the terms of the Creative Commons Attribution-NonCommercial-NoDerivs 3.0 Unported (CC BYNC-ND3.0) Licence (http://creativecommons.org/licenses/by-nc-nd/3.0/) which permits unrestricted noncommercial use, distribution, and reproduction in any medium, provided the original work is properly cited.

Please cite this article as: Tekeli H, Şenol MG, Özdağ F, Saraçoğlu M, Yaşar H, Kendirli MT, Altundağ A, Çayönü M, Salihoğlu M, Türker T. Evaluation of olfactory function in migraineurs during the migraine-free period with odor identification test. J Med Updates 2014;4(1):1-5. 